\title{
Effect of physical activity and fitness on executive functions and academic performance in children of elementary school. A systematic review
}

\section{Efectos de la actividad física y condición física sobre funciones ejecutivas y rendimiento académico en niños de Educación Primaria. Una revisión sistemática}

\author{
Beatriz Berrios Aguayo ${ }^{1}$, Pedro Ángel Latorre Román ${ }^{2}$, Jesús Salas Sánchez ${ }^{3,4^{*}}$, Antonio Pantoja Vallejo ${ }^{1}$ \\ ${ }^{1}$ Departamento de Pedagogía. Universidad de Jaén, España \\ 2 Departamento de Didáctica de la Expresión Musical, Plástica y Corporal. Universidad de Jaén, España \\ ${ }^{3}$ Universidad Autónoma de Chile, Chile \\ ${ }^{4}$ Facultad de Educación. Universidad Internacional de la Rioja \\ *Correspondence: jsalas@ \\ ujaen.es \\ HOW TO CITE THIS ARTICLE: \\ Berrios-Aguayo, B., Latorre-Román, P.A., Salas-Sánchez, J., \& Pantoja-Vallejo, A. \\ (2022). Effect of physical activity and fitness on executive functions and academic \\ performance in children of elementary school. A systematic review. Cultura, \\ Ciencia y Deporte, 17(51), 85-103. http://dx.doi.org/10.12800/ccd.v17i51.1699.
}

Received: 26 February 2021 / Accepted: 27 November 2021

\section{Abstract}

This systematic review sought to investigate the influence of physical activity and physical fitness on cognitive functions and academic performance. Studies were identified in four databases from January 2010 through January 2021. A total of 26 studies were selected after meeting the established criteria. Nine studies showed an association between physical activity and physical fitness variables and academic performance. Cardiorespiratory fitness, speedagility, motor coordination, and perceptual-motor skill had the strongest association with executive function, including attention, memory, inhibition and shifting in 17 studies. High levels of physical activity and physical fitness are associated with higher academic performance and executive function. More hours of Physical Education are needed to more effectively develop the cognitive aspects and physical fitness of children in elementary school.

Keywords: Physical performance, cognitive functions, academic achievement, school-aged children..

\section{Resumen}

Esta revisión sistemática buscó investigar la influencia de la actividad física y la aptitud física en las funciones cognitivas y el rendimiento académico. Los estudios se identificaron en cuatro bases de datos desde enero de 2010 hasta enero de 2021. Se seleccionaron un total de 26 estudios después de cumplir con los criterios establecidos. Nueve estudios mostraron una asociación entre la actividad física y las variables de aptitud física y el rendimiento académico. La aptitud cardiorrespiratoria, la velocidadagilidad, la coordinación motora y la habilidad perceptivomotora tuvieron la asociación más fuerte con la función ejecutiva, incluida la atención, la memoria, la inhibición y el cambio en 17 estudios. Los altos niveles de actividad física y aptitud física están asociados con un mayor rendimiento académico y función ejecutiva. Se necesitan más horas de Educación Física para desarrollar de manera más efectiva los aspectos cognitivos y la aptitud física de los niños en la escuela primaria.

Palabras clave: Desempeño físico, funciones cognitivas, rendimiento académico, niños en edad escolar. 


\section{Introduction}

The importance of physical activity (PA) for health and quality of life is well known and researched. Children experience both physical and psychological benefits when participating in PA (Ahn and Fedewa, 2011; Janssen and Leblanc, 2010; Lobelo et al., 2020). Moreover, previous studies have shown that PA influences cognitive functions (Ellemberg and St-Louis-Deschênes, 2010; Gallotta et al., 2014; Gunnell et al., 2019; Verburgh et al. 2014). A recent review showed that physical fitness (PF), single bouts of PA, and PA interventions benefit children's cognitive functioning (Donnelly et al., 2016). Children who demonstrated to have high physical aptitudes exhibited greater cortical activation and corresponding cognitive functions than less fit children (Álvarez-Bueno et al., 2017; Latorre Román et al., 2017; Lemes et al., 2021). Chaddock, Pontifex, Hillman and Kramer (2011) demonstrated how PA improved brain health and cognitive functions during child development. Chang et al. (2012) and Gallotta et al. (2014) showed that several variables associated with PA such as PA duration, PA intensity and specific types of PA performed during a training programme were significant moderators in the association between cognitive functions and PA.

The terms PA and PF are often confused. Although these terms are closely related, they should not be treated as synonyms. PA refers to any bodily movement produced by skeletal muscle which requires consumption of energy. PF in turn is interpreted as a measure of the capacity to perform PA that include the majority of the physical functions (skeletomuscular, CRF, hematocirculatory, endocrine-metabolic, and psycho-neurological) involved in PA. PF is made up of 3 components: cardiorespiratory fitness (CRF), strength, and agility (Martínez-Vizcaíno and SánchezLópez, 2008). The close relationship between these terms is what justifies attending to both in this systematic review.

Previous studies have found several associations between PA and cognitive functions on specific factors such as academic performance (AP), executive function (EF), memory, intellectual maturity, concentration, and creativity in children (Donnelly et al., 2016; Latorre-Román et al., 2016; Lees and Hopkins, 2013; Soga, Shishido and Nagatomi, 2015). These studies analysed both acute and chronic effects of PA on cognitive actions. In addition, literature reviews (e.g. Marques et al., 2018) show how higher cardiorespiratory fitness (CRF) may be important to enhance academic performance.

Academic performance can be improved through PA at school (Carriedo and González, 2019). Wittberg et al. (2012) demonstrated how students who have healthy PF had significantly higher scores in different school subjects than students who had a low level of PF. In addition, current research has shown that AP was higher when children completed an intervention dedicated to doing more PA at school (Resaland et al., 2015; Donnelly et al., 2013).

Aerobic exercises have the potential to promote multiple facets of development through its direct impact on $E F$ (Best, 2010). The term EF makes reference to capabilities we utilise when we formulate our goals and objectives, organise and plan, and when we carry out a series of adjusted and effective behaviours to achieve a goal (Lezak, Howieson and Loring, 2004). Multiple cognitive functions such as inhibiting dominant responses, updating working memory representations, shifting between task sets and attention are included in EF (Friedman et al., 2008). Working memory is an important element which belongs with EF. Pesce et al. (2009) investigated the effects of PA on memory performance in children through two sessions immediately following a PE class (aerobic circuit training vs. team games). They found that memory improved in both experimental groups compared to the control group. In addition, Berrios Aguayo et al. (2019) demonstrated the effectiveness of two PE classes (team game exercise and aerobic exercise) on memory. Additionally, attentional control and selective attention are other components of EF (Anderson, 2002). Mahar (2011) showed how after a break from a PE class, attention on a task was better. Syväoja et al. (2014) found that sedentary behaviour was associated with weaker flexibility of attention.

Different variables for PA have been associated with childhood neurocognition, however how cognitive aspects in children are developed through their physical development are still poorly understood. Further research is necessary to understand the relationship between PA and cognition performance during development. Mahar et al. (2006) claimed opportunities to be physically active at school are limited by pressure on scholastic performance. The incorporation of PA time into the school day is needed (Kibbe et al., 2011; SeguraMartínez et al., 2020).

Considering all previous evidence about how the practice of PA is related to greater cognitive and academic development in school-aged children, the research question focuses on: is there enough research literature that analyse this issue? Therefore, the objective of this systematic review was to analyse research that investigated the relationship and/or influence of PA and the level of PF on AP and EF in school-age children.

\section{Method}

The study was designed following the structure and recommendation of other systematic reviews (Ruiz-Ariza et al., 2017; García-Pinillos et al., 2016), the protocol used by PRISMA guidance for reports and studies (Moher, Liberati, Tetzlaff, Altman and PRISMA Group, 2009) and the Cochrane Manual of systematic reviews of interventions (Higgins and Green, 2011).

Search strategy

A comprehensive search of 4 databases (Medline, Pubmed, Eric ProQuest and Web of Science) from January 2010 through to January 2021 was undertaken. The principal categories of search terms were identified and employed in different combinations using "AND" (combining terms by retrieving the records in which all the searched terms appear) and "OR" (joining different terms by retrieving the records in which any of the terms appear) (Table 1). 
Table 1. Searcher strategy in databases

\begin{tabular}{|c|c|c|c|}
\hline Databases & Research Strategy & Limits & Filters \\
\hline Medline (EBSCO) & $\begin{array}{l}\text { (physical education OR physical } \\
\text { fitness OR physical activity) AND } \\
\text { (cognitive performance OR academic } \\
\text { performance OR attention OR } \\
\text { executive function OR memory) AND } \\
\text { (children OR childhood) }\end{array}$ & $\begin{array}{l}\text { Publication date: } \\
\text { 2010-2021 } \\
\text { English language } \\
\text { Age: 6-12 years } \\
\text { Free full text }\end{array}$ & 5623 \\
\hline Pubmed & $\begin{array}{l}\text { (physical education OR physical } \\
\text { fitness OR physical activity) AND } \\
\text { (cognitive performance OR academic } \\
\text { performance OR attention OR } \\
\text { executive function OR memory) AND } \\
\text { (children OR childhood) }\end{array}$ & $\begin{array}{l}\text { Publication date: } \\
\text { 01/01/2010-01/01/2021 } \\
\text { Humans } \\
\text { Age: 6-12 years. } \\
\text { English language } \\
\text { Linked full text }\end{array}$ & 2343 \\
\hline Eric Proquest & $\begin{array}{l}\text { (physical fitness OR physical } \\
\text { education OR physical activity) AND } \\
\text { (cognitive performance OR academic } \\
\text { performance OR attention OR } \\
\text { executive function OR memory) AND } \\
\text { (children OR childhood) }\end{array}$ & $\begin{array}{l}\text { Publication date: } \\
\text { 01/01/2010-01/01/2021 } \\
\text { English language } \\
\text { Journal Articles } \\
\text { Elementary education }\end{array}$ & 143 \\
\hline Web of Science & $\begin{array}{l}\text { ((physical education' OR' physical } \\
\text { activity' OR 'physical fitness') } \\
\text { (cognitive performance' OR 'academic } \\
\text { performance' OR attention OR } \\
\text { executive function OR memory) } \\
\text { (children OR childhood)) }\end{array}$ & $\begin{array}{l}\text { Publication date: } \\
\text { 2010-2021 } \\
\text { English language } \\
\text { Articles } \\
\text { Open access }\end{array}$ & 1783 \\
\hline
\end{tabular}

\section{Inclusion and exclusion criteria}

The relevant papers selected for inclusion in the review were checked against the following criteria:

(1) There were no exclusion criteria with regard to sex or ethnic origin; (2) There was exclusion with children with physical or intellectual disabilities. (3) Age: children aged between 6-12 years old; (4) Language: English; (5) Year of publication: 2010-2021; (6) The systematic review uses crosssectional, repeated measures or interventional studies; (7) Review articles were not included in this systematic review.
Reliability and data extraction

Based on the inclusion and exclusion criteria, two independent reviewers screened the citations of potentially relevant publications. If the citation showed any potential relevance, it was screened at the abstract level. When abstracts indicated potential inclusion, full-text articles were reviewed. A third-party consensus meeting was held with a third author (APV) if the 2 reviewers were not able to reach agreement. In conclusion, authors reviewed the studies resulting from the systematic review and agreed on their inclusion. 


\section{Quality assessment and level of evidence}

The quality assessment of the study has carried out on the basis of other standardised assessment lists. Cross-sectional studies were assessed using the modified version of the Quality Index developed by Downs and Black (Downs and Black, 1998) (Table 2). The original scale was reported to have good test-retest $(.=0.88)$ and inter-rater $(.=0.75)$ reliability and high internal consistency (Kuder-Richardson Formula 20
$(K R-20)=0.89)$. Reliability of the subscales varied from good to poor validity. The Quality Index correlated highly with an existing, established instrument for assessing randomised studies $r=0.90$. The modified version of the Downs and Black Quality Index is scored from 1 to 14 , with higher scores indicating higher-quality studies. Those items that corresponded to the selected studies were selected based on the needs of the study, as well as relevant systematic reviews already published, such as the one by Ruiz-Ariza et al. (2017).

Table 2. List of included studies with quality score (Down and Black scale modified)

\begin{tabular}{|c|c|c|c|c|c|c|c|c|c|c|c|c|c|c|c|}
\hline Authors and variables & $\begin{array}{l}\text { Item } \\
1\end{array}$ & $\begin{array}{l}\text { Item } \\
2\end{array}$ & $\begin{array}{l}\text { Item } \\
3\end{array}$ & $\begin{array}{l}\text { Item } \\
6\end{array}$ & $\begin{array}{l}\text { Item } \\
7\end{array}$ & $\begin{array}{l}\text { Item } \\
10\end{array}$ & $\begin{array}{l}\text { Item } \\
12\end{array}$ & $\begin{array}{l}\text { Item } \\
15\end{array}$ & $\begin{array}{l}\text { Item } \\
16\end{array}$ & $\begin{array}{l}\text { Item } \\
18\end{array}$ & $\begin{array}{l}\text { Item } \\
20\end{array}$ & $\begin{array}{l}\text { Item } \\
22\end{array}$ & $\begin{array}{l}\text { Item } \\
23\end{array}$ & $\begin{array}{l}\text { Item } \\
25\end{array}$ & $\begin{array}{l}\text { Total Score } \\
\text { (out of 14) }\end{array}$ \\
\hline Wittberg, Northrup and Cottrell (2012) & 1 & 1 & 1 & 1 & 1 & 1 & 1 & 1 & 1 & 1 & 1 & 1 & 0 & 0 & 12 \\
\hline Hansen et al. (2014) & 1 & 1 & 1 & 1 & 1 & 1 & 1 & 1 & 1 & 1 & 1 & 1 & 0 & 1 & 13 \\
\hline Haapala et al. (2014) & 1 & 1 & 1 & 1 & 1 & 1 & 0 & 1 & 1 & 1 & 1 & 1 & 1 & 1 & 13 \\
\hline van der Niet et al. (2015) & 1 & 1 & 1 & 1 & 1 & 1 & 0 & 1 & 1 & 1 & 1 & 1 & 1 & 0 & 12 \\
\hline van den Berg et al. (2016) & 1 & 1 & 1 & 1 & 1 & 0 & 0 & 1 & 1 & 1 & 1 & 1 & 1 & 0 & 11 \\
\hline Pontifex et al. (2012) & 1 & 1 & 1 & 1 & 1 & 1 & 0 & 1 & 1 & 1 & 1 & 1 & 1 & 1 & 13 \\
\hline Gallotta et al. (2015) & 1 & 1 & 1 & 1 & 1 & 1 & 0 & 1 & 1 & 1 & 1 & 1 & 1 & 1 & 13 \\
\hline Jäger et al. (2015) & 1 & 1 & 1 & 1 & 1 & 1 & 0 & 1 & 1 & 1 & 1 & 1 & 1 & 0 & 12 \\
\hline Schmidt et al. (2015) & 1 & 1 & 1 & 1 & 1 & 1 & 0 & 1 & 1 & 1 & 1 & 1 & 1 & 0 & 12 \\
\hline Pirrie and Lodewyk (2012) & 1 & 1 & 1 & 1 & 1 & 1 & 0 & 1 & 1 & 1 & 1 & 1 & 1 & 1 & 13 \\
\hline Schmidt et al. (2017) & 1 & 1 & 1 & 1 & 1 & 1 & 1 & 1 & 1 & 1 & 1 & 1 & 1 & 1 & 14 \\
\hline
\end{tabular}

Note: 0 = no; 1 = yes; Item 1: clear aim/hypothesis; Item 2: outcome measures clearly described; Item 3: patient characteristics clearly described; Item 6:main findings clearly described; Item7:measures of random variability provided; Item10: actual probability values reported; Item12: participants prepared to participate representative of entire population; Item 15: Blinding of outcome measures; Item 16: analysis completed was planned; Item 18: appropriate statistics; Item 20: valid and reliable outcome measures; Item 22: participants recruited over same period; Item 23: Randomised; Item 25: adjustment made for confounding variables.

The methodological quality of interventional studies was assessed using the Physiotherapy Evidence Database (PEDro) scale (Maher et al., 2003) (Table 3). This 11-item scale rates randomised controlled trials from 0 to 10 , with 6 representing the cut off score for high-quality studies. Studies scoring 9-10 on the PEDro scale were considered to be of "excellent" methodologically quality, 6-8 of "good" quality, 4-5 of "fair" quality, and below 4 of "poor" quality. 
Table 3. List of included longitudinal studies with quality scores (PEDro scale)

\begin{tabular}{|c|c|c|c|c|c|c|c|c|c|c|c|c|c|}
\hline Authors and variables & $\begin{array}{l}\text { Item } \\
1\end{array}$ & $\begin{array}{l}\text { Item } \\
2\end{array}$ & $\begin{array}{l}\text { Item } \\
3\end{array}$ & $\begin{array}{l}\text { Item } \\
4\end{array}$ & $\begin{array}{l}\text { Item } \\
5\end{array}$ & $\begin{array}{l}\text { Item } \\
6\end{array}$ & $\begin{array}{l}\text { Item } \\
7\end{array}$ & $\begin{array}{l}\text { Item } \\
8\end{array}$ & $\begin{array}{l}\text { Item } \\
9\end{array}$ & $\begin{array}{l}\text { Item } \\
10\end{array}$ & $\begin{array}{l}\text { Item } \\
11\end{array}$ & $\begin{array}{l}\text { Total } \\
\text { Score }\end{array}$ & $\begin{array}{l}\text { Quality } \\
\text { level }\end{array}$ \\
\hline Mullender-Wijnsma et al. (2015) & 1 & 1 & 0 & 1 & 1 & 0 & 0 & 1 & 1 & 1 & 1 & 8 & GQ \\
\hline Käll, Nilsson \& Lindén (2014) & 1 & 0 & 0 & 1 & 1 & 0 & 0 & 1 & 1 & 1 & 1 & 7 & GQ \\
\hline Sardinha et al. (2016) & 1 & 0 & 0 & 1 & 1 & 0 & 0 & 1 & 1 & 1 & 1 & 7 & GQ \\
\hline Fisher et al. (2011) & 1 & 0 & 0 & 1 & 1 & 0 & 0 & 1 & 1 & 1 & 1 & 7 & GQ \\
\hline Kamijo et al. (2011) & 1 & 1 & 0 & 1 & 1 & 0 & 0 & 1 & 1 & 1 & 1 & 8 & GQ \\
\hline Ou et al. (2016) & 1 & 1 & 0 & 1 & 1 & 0 & 0 & 1 & 1 & 1 & 1 & 8 & GQ \\
\hline de Greeff et al. (2016) & 1 & 1 & 0 & 1 & 1 & 0 & 0 & 1 & 1 & 1 & 1 & 8 & GQ \\
\hline Layne et al. (2021) & 1 & 1 & 1 & 1 & 1 & 0 & 0 & 1 & 1 & 1 & 1 & 9 & EQ \\
\hline
\end{tabular}

Note. $0=$ item was not satisfied; $1=$ item was satisfied Excellent quality $(E Q)=9-10$; Good quality $(G Q)=6-8 ;$ Fair quality $(F Q)=4-5$; Poor quality $(P Q)=<4$; Item 1: eligibility criteria were specified; Item 2: subjects were randomly allocated to groups; Item 3: allocation was concealed; Item 4:The groups were similar at baseline regarding the most important prognostic indicators; Item 5:There was blinding of all subjects; Item 6:There was blinding of all therapists who administered the therapy; Item 7: There was blinding of all assessors who measured at least one key outcome; Item 8: measurements of at least one key outcome were obtained from more than $85 \%$ of the subjects initially allocated to groups; Item 9: all subjects for whom outcome measuments were available received the treatment or control condition as allocated, or where this was not the case, data for at least one key outcome were analyzed by "intention to treat"; Item 10: the results of between groups statistical comparisons are reported for at least one key outcome; Item 11: the study provides both point measurements and measurements of variability for at least one key outcome.

Result

The flow of search results through the systematic review process is shown in Figure 1. Firstly, 9892 papers from the different databases were extracted based on the language, type of document, age and date. Secondly, duplicate papers were excluded (4562 duplicate papers). Then, the titles of the articles were read to exclude those that were not related with our bibliographical search (123 papers were selected). Specifically, population, age, language, design, variables, and other excluding factors were meticulously inspected. Finally, 123 papers were read in full in order to select the final sample (28 papers) (Table 4)

A meticulous analysis was conducted with the final papers. Nine papers $(32,14 \%)$ were cross-sectional studies (Wittberg et al. 2012; Lambourne et al., 2013; Hansen et al., 2014; Haapala et al., 2014; Syväoja et al., 2014; van der Niet et al., 2015; Pontifex et al., 2012; Raine et al., 2013; Schmidt et al. 2017); six papers $(21,42 \%)$ were repeated measures studies (van den Berg et al., 2016; Gallotta et al., 2015; Ma et al., 2015; Jäger et al., 2015; Schmidt et al., 2015; Pirrie and Lodewyk, 2012). Both cross-sectional studies and repeated measures studies were methodologically assessed through the modified Down and Black scale providing an adequate assessment of the articles based on the scale scores. Finally, 13 papers $(46.42 \%)$ were interventional studies (Mullender-Wijnsma et al., 2015; Käll et al., 2014; Erwin et al., 2012; Hillman et al., 2014; Fisher et al., 2011; Kamijo et al., 2011; Ou et al., 2016; de Greeff et al., 2016; Sardinha et al., 2016; Kvalø et al. 2017; Lind et al., 2018; Chaddock-Heyman et al., 2020; Layne et al., 2021) . These articles were assessed through the PEDro scales obtaining an evaluation of Good Quality or Excellent Quality.

The main findings of the studies analyzed in the systematic review agree that PA has an acute and chronic effect on the cognitive and academic performance of primary school children. The results will mainly depend on the intensity and the time of development of the PA. 
Table 4. Characteristic of the studies analysed

\begin{tabular}{|c|c|c|c|c|c|}
\hline Authors & $\begin{array}{ll}\text { Physical/ Cognitive } \\
\text { Variables }\end{array}$ & $\begin{array}{l}\text { Study design/ Duration } \\
\text { Sample/ Age/ Country }\end{array}$ & $\begin{array}{l}\begin{array}{l}\text { Procedure } \\
\text { measures. }\end{array}\end{array}$ & Cognitive function measures & Result \\
\hline $\begin{array}{l}\text { Wittberg et al. } \\
(2012)\end{array}$ & $\mathrm{CRF} / \mathrm{AP}$ & $\begin{array}{l}\text { Cross-sectional study/ } \\
1725 \text { students/5th grade } \\
\text { and } 7 \text { th grade/ Virginia, } \\
\text { USA }\end{array}$ & $\begin{array}{l}\text { Cardiorespiratory fitness: } \\
\text { Students did the Progressive Aerobic } \\
\text { Cardiovascular Endurance Run } \\
\text { (PACER) used in FitnessGram. This } \\
\text { test measures the time it takes the } \\
\text { child to run or walk } 1 \text { mile. With the } \\
\text { PACER assessment, the student is } \\
\text { expected to run back and forth across } \\
\text { a } 20 \text {-metre space at a pace defined on } \\
\text { a beep-only or music audiotape, } \\
\text { which gets faster each minute. }\end{array}$ & $\begin{array}{l}\text { Academic performance: } \\
\text { WESTEST (West Virginia } \\
\text { Educational Standards Test) } \\
4 \text { test areas: mathematics, science, } \\
\text { social studies, and reading and } \\
\text { language arts. }\end{array}$ & $\begin{array}{l}\text { Students who had better marks on } \\
\text { the CRF test obtained significantly } \\
\text { higher WESTEST scores than } \\
\text { students who had lower CRF } \\
\text { capacity. }\end{array}$ \\
\hline $\begin{array}{l}\text { Lambourne et al. } \\
\text { (2013) }\end{array}$ & $\mathrm{PA}$ and $\mathrm{CRF} / \mathrm{AP}$ & $\begin{array}{l}\text { Cross-sectional study/ } \\
687 \text { students/ } 2^{\text {nd }} \text { and } 3^{\text {rd }} \\
\text { grades/ Kansas, USA }\end{array}$ & $\begin{array}{l}\text { Daily PA assessed: } \\
\text { Children wore a portable } \\
\text { Accelerometer on a belt over the } \\
\text { non-dominant hip for at least } 10 \\
\text { hours on } 3 \text { days or more. } \\
\text { Cardiovascular fitness: children did the } \\
\text { PACER. }\end{array}$ & $\begin{array}{l}\text { Academic performance: } \\
\text { Weschsler Individual } \\
\text { Achievement Test-Third Edition } \\
\text { (WIAT-III). It assessment reading } \\
\text { comprehension and oral reading } \\
\text { fluency, spelling, and } \\
\text { mathematics problem solving and } \\
\text { numerical operations. }\end{array}$ & $\begin{array}{l}\text { Findings showed a direct effect of } \\
\text { PA on AF ( } b=0.009, p<0.001) \\
\text { and an indirect effect (mediation) of } \\
\text { PA via fitness on math achievement } \\
(\mathrm{b}=0.003, \mathrm{p}<0.01) \text {. However, PA } \\
\text { nor AF were correlated with WIAT- } \\
\text { III reading or spelling scores. }\end{array}$ \\
\hline
\end{tabular}

Note: $\mathrm{PA}=$ Physical activity; $\mathrm{PF}=$ Physical fitness; $\mathrm{PE}=$ Physical education; $\mathrm{MVPA}=$ moderate to vigorous physical activity; $\mathrm{AF}=\mathrm{Aerobic}$ fitness; $\mathrm{CRF}=\mathrm{Cardiorespiratory}$ fitness; PLACER = Progressive Aerobic Cardiovascular Endurance Run; BMI = Body mass index; $A P=$ Academic performance; $E F=$ Executive function

\section{Table 4 (cont.) Characteristic of the studies analysed}

$\begin{aligned} & \text { Hansen, at al. CRF/AP } \\ & (2014)\end{aligned}$
$\begin{aligned} & \text { Haapala et al. Motor performance, } \\ & \text { (2014) } \\ & \text { cardiovascular }\end{aligned}$
performance/AP Cross-sectional study/
687 students/ Mean age $=$
$7.8 \pm 0.6$ years from $2^{\text {nd }}$ USA

Physical activity:

To measure PA, children wore an GT3X ${ }^{+}$portable accelerometer on a belt over the non(including 1 for 4 consecutive days

Cardiorespiratory fitness:

To measure progressive
cardiovascular fitness, PACER was used.

Cross-section study/ 341 students/ 6-8 years from $1^{\text {st }}$ and 3

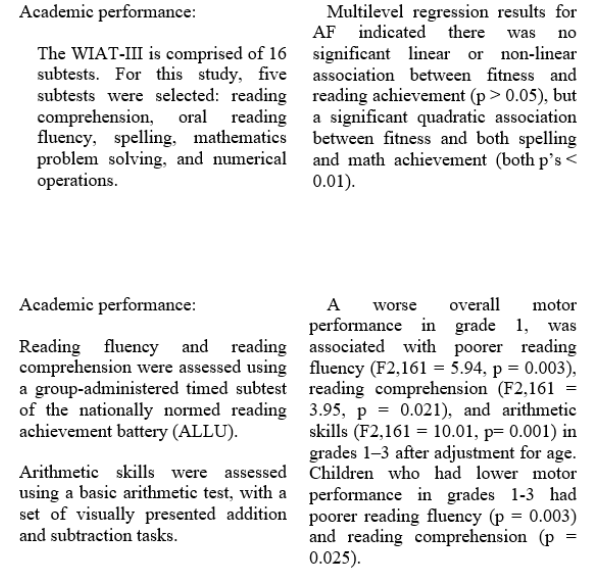

Motor performance:

The shuttle run test was used to assess speed and agility. The flamingo balance test was used to assess static balance. The box and block test was used to assess manual dexterity. 
Table 4 (cont.) Characteristic of the studies analysed

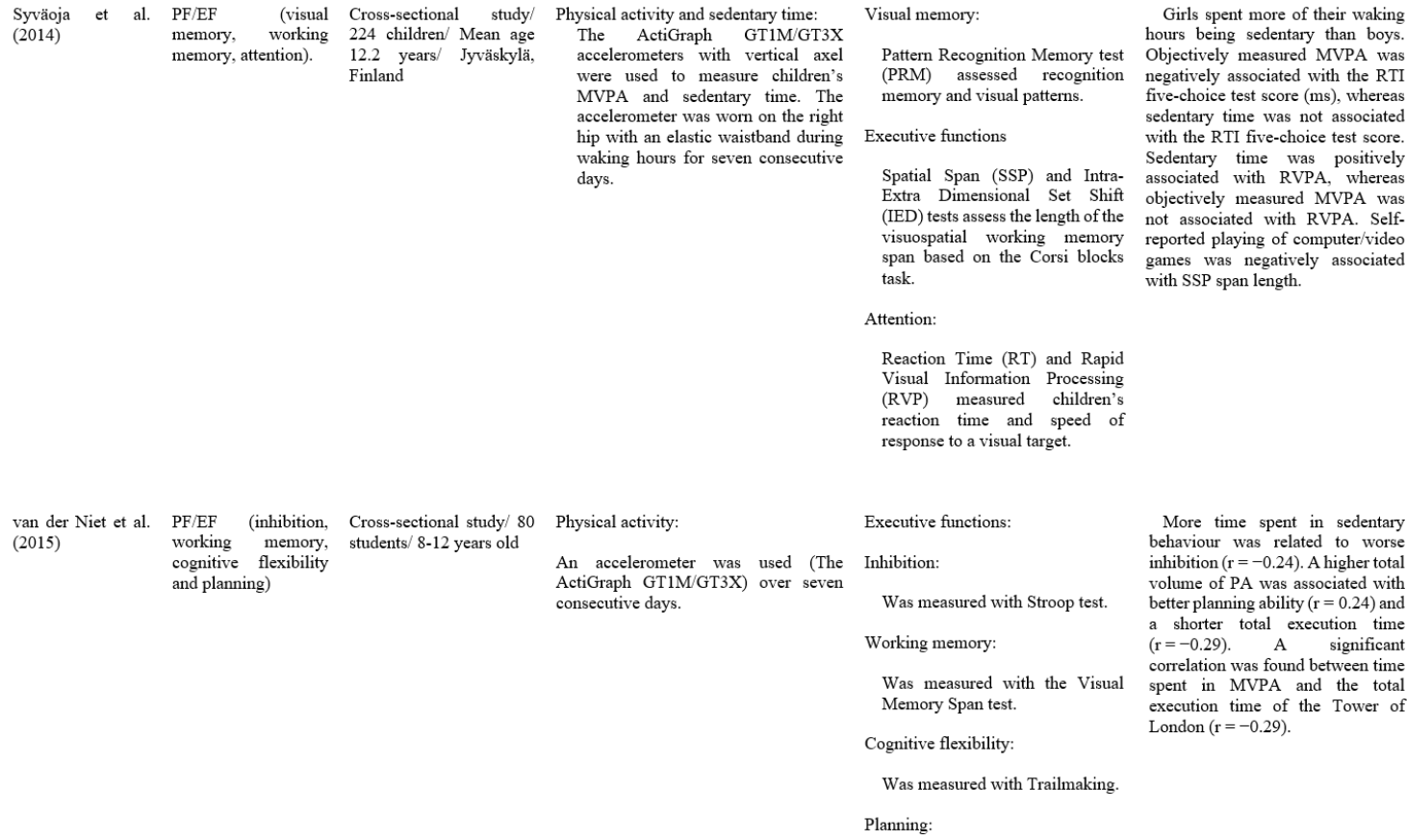

Table 4 (cont.) Characteristic of the studies analysed

Children used Tower of London test in order to measure planning.

Pontifex et al. Poor (2012)

\begin{abstract}
$\mathrm{EF}$ (attention)
\end{abstract}

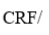

\section{Cross-sectional study/ 62
students/ 9 -10 years old $/$ East-central Illinois region, USA}

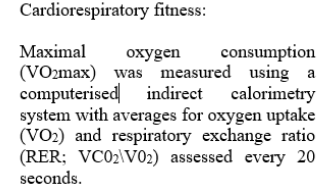

seconds.
Poor attention:

The ADHD Rating Scale IV is an 18-item inventory completed by the parent/legal guardian based upon the diagnostic criteria for attention deficit hyperactivity

Pubertal status:

The Tanner Pubertal Timing Scales use self-ratings based upon
schematic drawings of secondary schematic drawings of

Intelligent:

The K-BIT assessed the verbal and nonverbal intelligence in individuals.
Findings showed that lower-fit cxhibited poorer overal esponse accuracy during a task equiring aspects of cognitive 政 counterparts, with deproportionate greater number of errors of omission, and longer, more frequent sequential errors of omission. 
Table 4 (cont.) Characteristic of the studies analysed

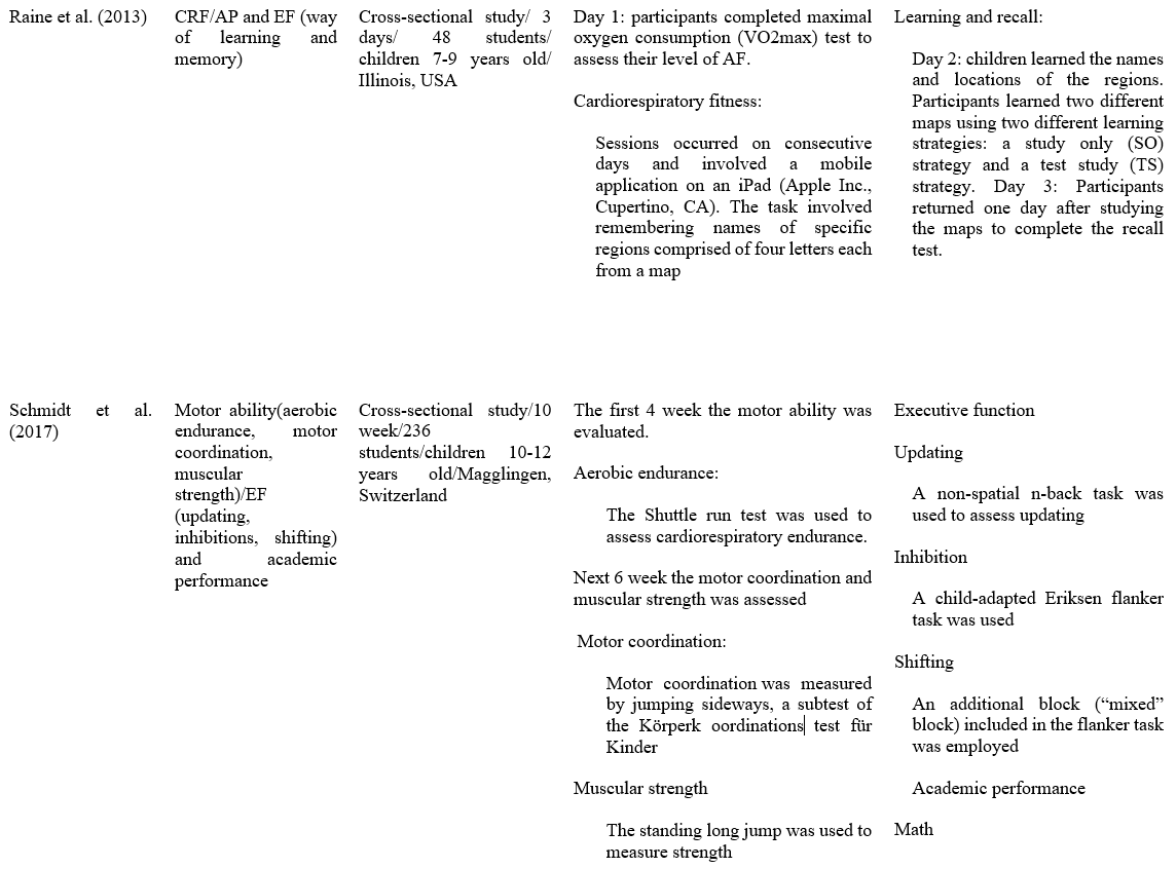

An additional block ("mixed" block) included in the flanker task was employed

Academic performance

.

\section{Table 4 (cont.) Characteristic of the studies analysed}

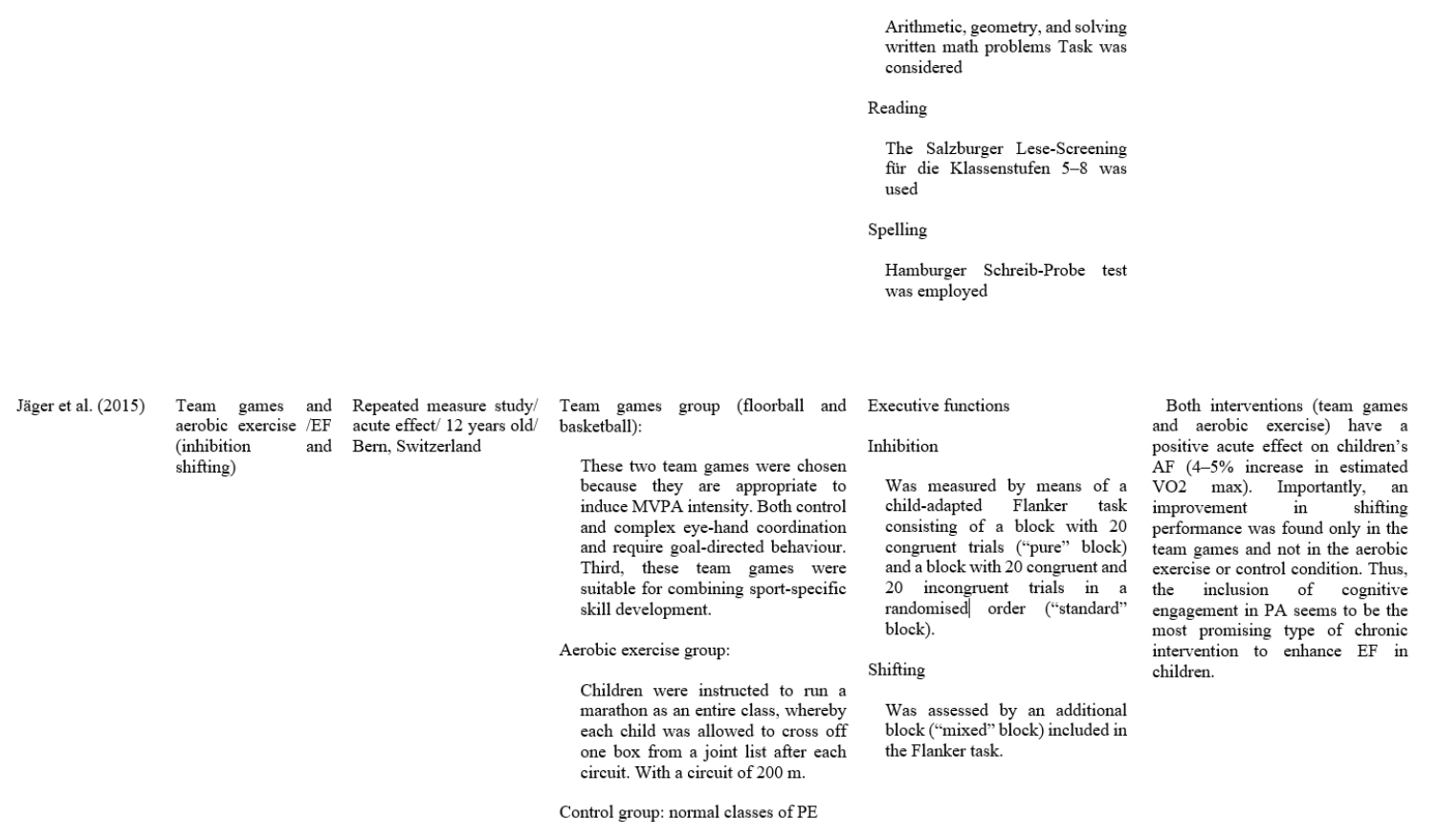

There were no differences in performance at initial learning between higher fit and lower fit participants. However, during the
retention session higher fit children particularly when the initial learning strategy involved relatively poor recall performance. Fitness can boost learning and memory of children and these fitness-associated performance benefits are largest in conditions in which initial learning is the most challenging.

A mediation analysis was used to show how EF was a mediator variable for the three physical variables . However, there was only coordination and the AP. It concludes by showing an indirect through the EF outperformed lower fit children, path of physical skills and the AP

(n)


Table 4 (cont.) Characteristic of the studies analysed

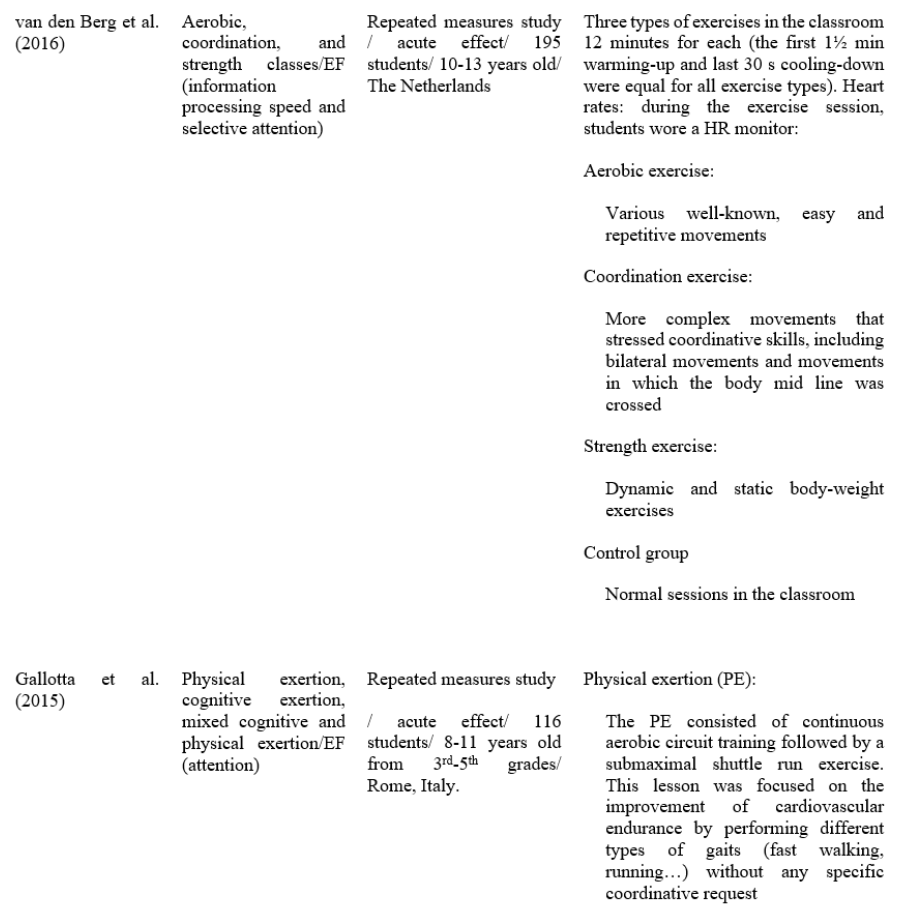

Gallotta
(2015)

Rome, Italy.

The PE consisted of continuous aerobic circuit training followed by a submaximal shuttle run exercise.
This lesson was focused on the improvement of cardiovascula endurance by performing differen types of gaits (fast walking. types of gaits (fast walking, coordinative request

nformation processing speed:

'. Above and/or below each letter individenty or insplayed, eit individually or in pairs.
Table 4 (cont.) Characteristic of the studies analysed

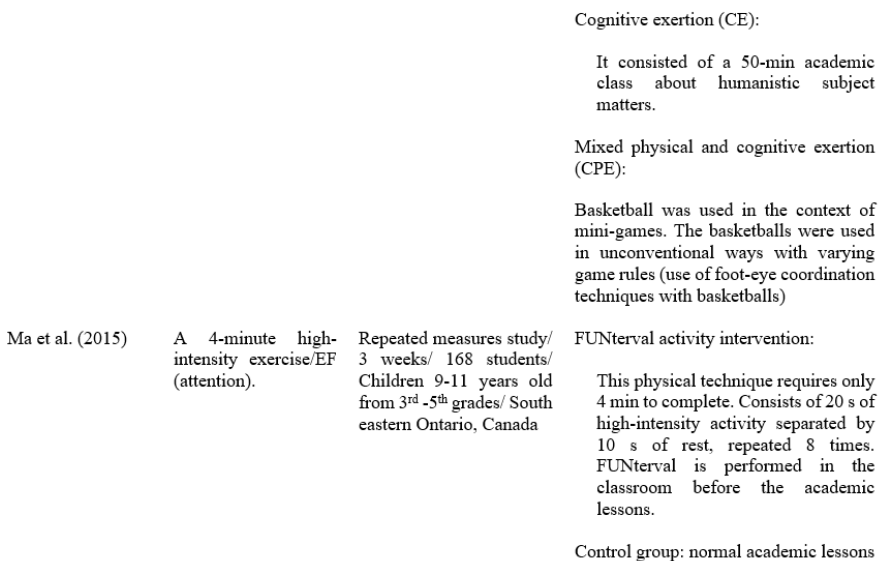

The Letter Digit Substitution Test (LDST) requires students to $0.71, \mathrm{p}=0.40, \eta 2 \mathrm{p}=0.00]$ and match letter-number pairs selective attention $[\mathrm{F}(1,172)=$ according to a key, which is $0.91, \mathrm{p}=0.34, \eta 2 \mathrm{p}=0.01]$ presented tontop of the sheet. The Likewise, type of PA did not key contains nine boxes with moderate effects on information associated numbers, $\begin{array}{ll}\text { Selective attention: } & 0.60, \mathrm{p}=0.55, \eta 2 \mathrm{p}=0.01] \text {. Pre- and } \\ \text { post-test scores showed similar }\end{array}$ Students performed the D2 test. It patterns on the exercise and control consists of one page with 14 lines, day, and did not differ between each consisting of 47 letters ' $d$ ' and exercise types.

Attention:

Children, before the intervention classes and just after these, used the $\mathrm{D} 2$ test in order to assess $\mathrm{p}$
and post selective/attention. 
Table 4 (cont.) Characteristic of the studies analysed

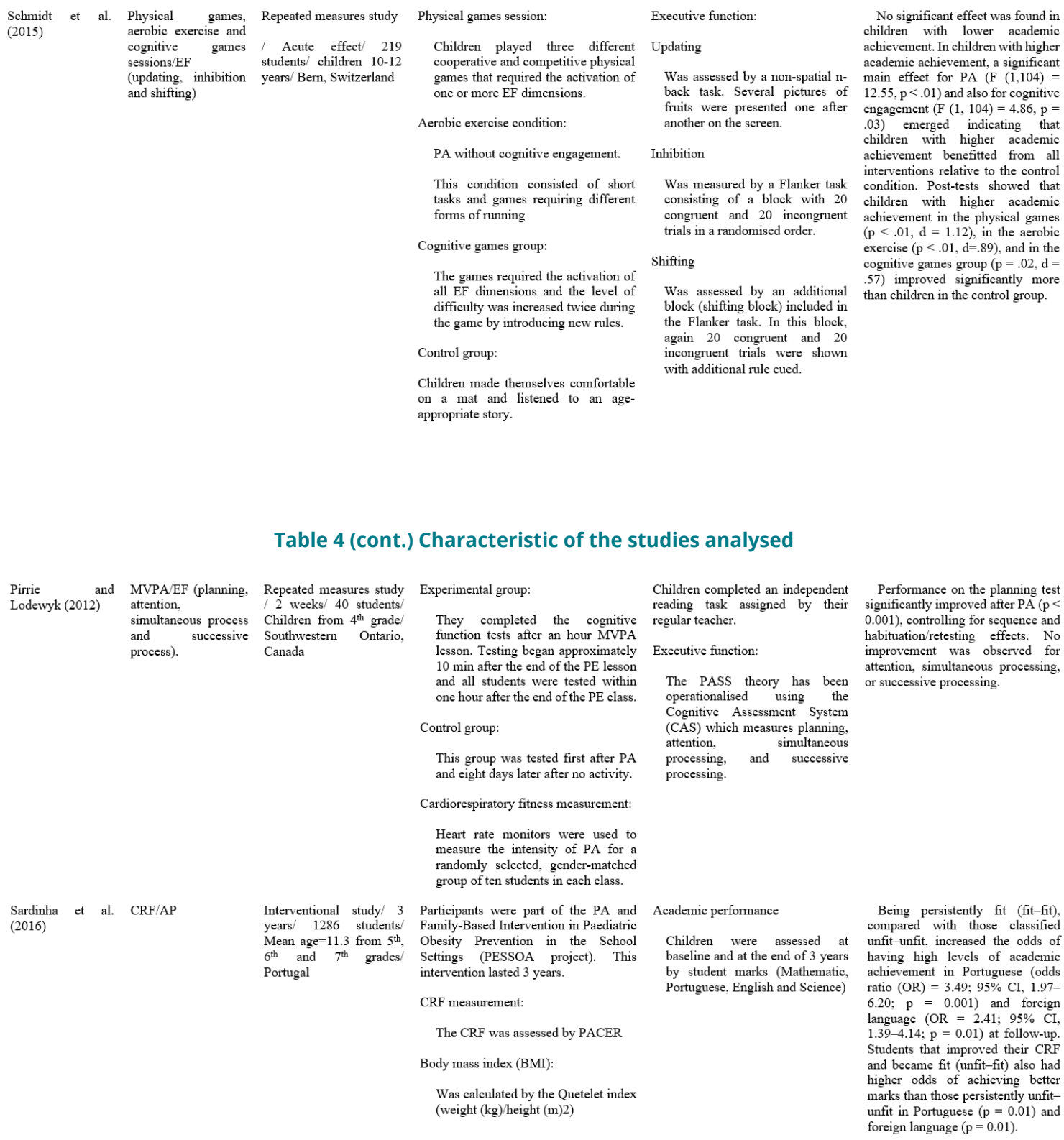


Table 4 (cont.) Characteristic of the studies analysed

\begin{tabular}{|c|c|c|c|c|c|c|}
\hline Käll et al. (2014) & $\begin{array}{l}\text { Increasing } \\
\text { classes/AP }\end{array}$ & PE & $\begin{array}{l}\text { Interventional study / } \\
1965 \text { students/ elementary } \\
\text { school/Sweden }\end{array}$ & $\begin{array}{l}\text { Experimental group: } \\
\text { Children were carrying out a } \\
\text { Swedish government programme } \\
\text { (Handslaget), using group play, and } \\
\text { other activities. } \\
\text { Control group: } \\
\begin{array}{l}\text { Student did not increase PA } \\
\text { sessions. }\end{array}\end{array}$ & $\begin{array}{l}\text { Academic performance: } \\
\text { National goals in Swedish, } \\
\text { Mathematics, and } \\
\text { English. Academic results from } \\
\text { the years prior to and during the } \\
\text { intervention programme were } \\
\text { analysed. }\end{array}$ & $\begin{array}{l}\text { Higher proportions of students in } \\
\text { the experimental group achieved the } \\
\text { national goals in all } 3 \text { subjects } \\
\text { compared with the control group } \\
\text { which obtain lower results. }\end{array}$ \\
\hline $\begin{array}{l}\text { Mullender- } \\
\text { Wijnsma et al. } \\
\text { (2015) }\end{array}$ & $\begin{array}{l}\text { Active } \\
\text { lesson/AP }\end{array}$ & academic & $\begin{array}{l}\text { Interventional study/ } 1 \\
\text { year/ } 228 \text { children }(122 \\
\text { boys and } 106 \text { girls) } / \text { Mean } \\
\text { age: } 8.1 \text { from } 2^{\text {2d }} \text { or } 3^{\text {rd }} \\
\text { grades/ Netherlands }\end{array}$ & $\begin{array}{l}\text { Experiment group: } \\
\text { Children have to do MVPA during } \\
\text { F\&V lessons (Fit \& Vaardig op } \\
\text { school; Fit and academically } \\
\text { proficient at school) in the } \\
\text { classroom (jumping while spelling } \\
\text { words, moving around the class } \\
\text { saying exercise results, etc.) } \\
\text { Control group: } \\
\text { Normal lesson without PA }\end{array}$ & $\begin{array}{l}\text { Academic performance: } \\
\text { Observations were done during } \\
\text { the lesson. Investigators observed } \\
\text { whether children performed the } \\
\text { basic exercise (on-task), } \\
\text { the specific exercise (on-task) or } \\
\text { no/other exercise } \\
\text { (off-task) of maths and languages. }\end{array}$ & $\begin{array}{l}\text { The third-grade children in the } \\
\text { intervention group scored } \\
\text { significantly higher on both } \\
\text { mathematics ( } \mathrm{F}[1,99]=11.72, \mathrm{p}< \\
.05) \text { and reading }(\mathrm{F}[1,98]=6.97, \mathrm{p}< \\
.05) \text { in comparison with the third- } \\
\text { grade children in the control group. } \\
\text { On the other hand, the second-grade } \\
\text { children in the intervention group } \\
\text { scored significantly lower on on } \\
\text { mathematics in comparison with the } \\
\text { second-grade children in the control } \\
\text { group }(\mathrm{F}[1,109]=12.40, \mathrm{p}<.05) \text {. } \\
\text { No differences were found on the } \\
\text { reading test in grade } 2(\mathrm{~F}[1,109]= \\
0.72, \mathrm{p}=.40)\end{array}$ \\
\hline Erwin et al. (2012) & $\begin{array}{l}\text { Active } \\
\text { lessons/AP }\end{array}$ & academic & $\begin{array}{l}\text { Interventional study/ } 20 \\
\text { week/ } 29 \text { students/ Mean } \\
\text { age: } 8.87 \text { from } 3^{\text {rd }} \text { grade/ } \\
\text { Kentucky, USA }\end{array}$ & $\begin{array}{l}\text { Experimental group: } \\
\text { Intervention children had PA breaks } \\
\text { for } 20+\text { minutes per day. Children } \\
\text { combined different PA like teacher- } \\
\text { directed instruction, partner or group } \\
\text { exercises around the classroom, etc. } \\
\text { To measure school day PA, } \\
\text { participants wore a pedometer for five } \\
\text { consecutive school days } \\
\text { Control group: }\end{array}$ & $\begin{array}{l}\text { Academic performance } \\
\text { Reading fluency was curriculum- } \\
\text { based while mathematical fluency } \\
\text { was assessed with short progress } \\
\text { measures designed to assess } \\
\text { children's reading and } \\
\text { mathematical abilities. } \\
\text { At the beginning and end of the } \\
\text { intervention, students carried out } \\
\text { the Test of Primary Reading } \\
\text { Outcomes (T-PRO), which }\end{array}$ & $\begin{array}{l}\text { The intervention group }(\mathrm{M}= \\
24.56, \mathrm{SD}=2.21) \text { scored } \\
\text { significantly higher in mathematics } \\
\text { than the control group }(\mathrm{M}=13.69 \text {, } \\
\mathrm{SD}=2.45) \text {. The scores in reading } \\
\text { were statistically higher than } \\
\text { standardised test scores }(\mathrm{p}<.001) \text {. }\end{array}$ \\
\hline
\end{tabular}

Table 4 (cont.) Characteristic of the studies analysed

They did normal academic classes in the classroom assesses phonics, vocabulary,
comprehension, and research skills.

Attentional inhibition

Assessed using a modified flanker task. Cognitive flexibility was assessed by using a colour-shape switch task. A modified flanker task is a method to measure inhibition in which children are engaged in a series of trials that, in this case, have arrays of fish that either match (congruent arrays) or arrays). intently particis. . intervention included 30-40 minutes TA stations. Next, a healthy snac and educational component were then engaged in low organisational games (45-55 minutes) centred on skill theme.

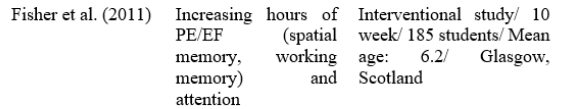

Cognitive function:
The Cognitive Assessment
System (CAS), the Cambridge
Neuropsychological Test Battery (CANTAB)

Attention:
Response accuracy increased in both groups, however, the intervention group demonstrated to post-test than the wait-list contro group $(3.2 \%, 95 \%$ CI: 0.0 to $6.5, \mathrm{~d}=$ 0.27 for group difference in pre-toost change score. The improvement in performance on the heterogeneous task was greater among intervention participants $(4.8 \%, 95 \%$ CI: 1.1 to $8.4, \mathrm{~d}=0.3$ for group difference in pre-to-post change score. 
Table 4 (cont.) Characteristic of the studies analysed

\begin{tabular}{|c|c|c|c|c|c|}
\hline & & & $\begin{array}{l}\text { Control group: } \\
\text { Only } 1 \text { class of PE per week }\end{array}$ & $\begin{array}{l}\text { The Attention Network Test } \\
\text { (ANT). } \\
\text { Memory: } \\
\text { The test of Spatial Memory Span } \\
\text { (SSP) and the test of Spatial } \\
\text { Working Memory (SWM). }\end{array}$ & $\begin{array}{l}\text { suffering cognitive Problems/ } \\
\text { Inattention, Hyperactivity and } \\
\mathrm{ADHD} \text { index were significantly } \\
\text { lower post intervention than in the } \\
\text { control group. }\end{array}$ \\
\hline $\begin{array}{l}\text { Kamijo et al. } \\
(2011)\end{array}$ & $\begin{array}{l}\text { Afterschool PA/EF } \\
\text { (working memory) }\end{array}$ & 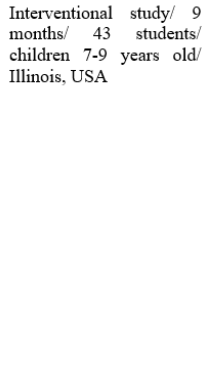 & $\begin{array}{l}\text { Physical activity intervention: } \\
\text { It occurred for a 2-hour period } \\
\text { following each school day, and } \\
\text { focused on improvement of CRF. } \\
\text { Muscle fitness was addressed at least } \\
2 \text { days a week, with the participants } \\
\text { using their own Thera-bands }{ }^{\circledR} \text {. The } \\
\text { sessions were around } 40 \text { min, } \\
\text { however there were lessons lasting } 70 \\
\text { min. } \\
\text { Cardiorespiratory fitness: } \\
\text { Maximal oxygen consumption } \\
\text { (VO2max) was measured using a } \\
\text { motor-driven treadmill and a } \\
\text { modified Balke protocol. }\end{array}$ & $\begin{array}{l}\text { Working memory: } \\
\text { A modified Sternberg task asked } \\
\text { participants to encode a memory } \\
\text { set containing an array of one, } \\
\text { three, or five letters and press one } \\
\text { of two buttons with their thumbs } \\
\text { corresponding to whether a single } \\
\text { probe letter was present (right) or } \\
\text { absent (left) in the encoded letter } \\
\text { array. }\end{array}$ & $\begin{array}{l}\text { The PA intervention led to } \\
\text { increases in CRF and improved } \\
\text { Sternberg task performance. } \\
\text { Further, the beneficial effects of the } \\
\text { PA intervention were greater for a } \\
\text { task condition requiring greater } \\
\text { working memory demands. In } \\
\text { addition, the intervention group } \\
\text { exhibited larger initial contingent } \\
\text { negative variation (CNV) at the } \\
\text { frontal electrode site, relative to the } \\
\text { control group. }\end{array}$ \\
\hline Ou et al. (2016) & $\begin{array}{l}\text { Afterschool } \\
\mathrm{PA} / \mathrm{EF} \text { (working } \\
\text { memory) }\end{array}$ & $\begin{array}{l}\text { Interventional study } / 10 \\
\text { weeks } / 71 \text { students/ Mean } \\
\text { age: } 9.4 \text { years/ } \\
\text { Westphalia, Germany }\end{array}$ & $\begin{array}{l}\text { The experimental groups had } 3 \\
\text { afterschool sessions per week for } 45 \\
\text { min. } \\
\text { The cardiovascular exercise group (CE): } \\
\text { Children focused on improvement of } \\
\text { cardiovascular fitness through } \\
\text { running and running-based games of } \\
\text { MVPA (recorded on three occasions } \\
\text { by F1 Polar HR monitors). } \\
\text { The motor exercise group (ME): }\end{array}$ & $\begin{array}{l}\text { Working memory: } \\
\text { Children used The Letter Digit } \\
\text { Span (LDS). The task involves a } \\
\text { standardised auditory } \\
\text { presentation of an increasing } \\
\text { mixed series of alternating } \\
\text { numbers and letters. After an } \\
\text { acoustic signal, each participant } \\
\text { was asked to respond by first } \\
\text { writing the numbers in order from } \\
\text { the smallest to the largest, }\end{array}$ & $\begin{array}{l}\text { Improvements in working } \\
\text { memory from pre- to post-test in the } \\
\text { two exercise groups were found with } \\
\text { large effect sizes (CE: } \mathrm{F}(1,26)= \\
19.709, \mathrm{p}=0.001, \mathrm{r}=0.66 ; \mathrm{ME}: \\
\mathrm{F}(1,22)=62.718, \mathrm{p}=0.001, \mathrm{r}= \\
0.86), \text { but not in the CO } \mathrm{F}(1,20)= \\
0.769, \mathrm{p}=0.391, \mathrm{r}=0.19) \text {. In the } \\
\text { post measurement, only the ME } \\
\text { differed significantly from the CO ( } \mathrm{t} \\
(68)=2.521, \mathrm{p}=0.014, \mathrm{r}=0.29), \text { but } \\
\text { not from the } \mathrm{CE}(\mathrm{t}(68)=0.746, \mathrm{p}= \\
0.458, \mathrm{r}=0.09), \text { nor did the CE }\end{array}$ \\
\hline
\end{tabular}

Table 4 (cont.) Characteristic of the studies analysed

\author{
Children focused on the improvement \\ the bilateral coordination, hand-eye \\ coordination, and leg-arm \\ coordination exercises as well as \\ spatial orientation and reaction to \\ moving objects/persons \\ Control group (CO): normal PE classes \\ followed by writing the letters in
$\begin{aligned} & \text { differ significantly from the CO ( } \mathrm{t} \\ & \text { alphabetical order. }\end{aligned}$
$(68)=1.887, \mathrm{p}=0.063, \mathrm{r}=0.22)$.
}

A great improvement in speedand a lower $(B=-0.70, p=0.002)$ strength $(B=-0.92, p<0.001)$ satic found for the intervention woup. There was no significant between intervenionificant rest a duration of 20-30 Fent on solving $\min$ spent on language. They had MVPA intensity. During the F\&V lessons all children started with performing a basic exercise, such as jogging, hopping in place o performed when the children solved an academic task.

Control group:

The Digit span backward and Visual span backward were used.

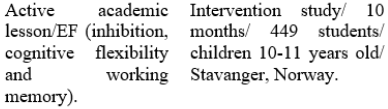

Executive function measurement:

This $\mathrm{EF}$ was measured by The $\mathrm{EF} \quad \mathrm{F}(1,344)=3.64, \quad \mathrm{P}=.057$ However, the results were positive. 


\section{Identification of studies via databases}
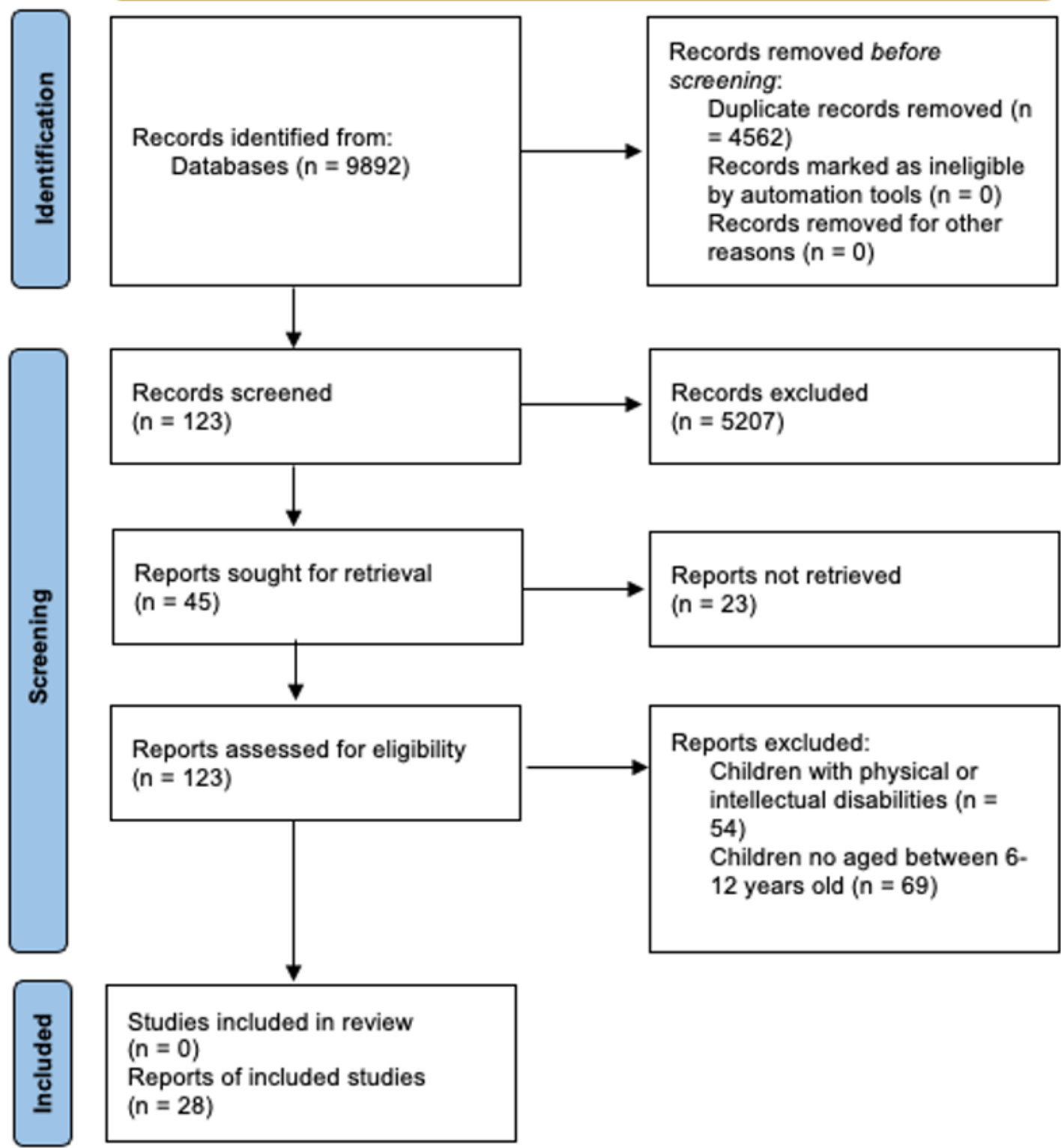

$$
\begin{aligned}
& \text { Studies included in review } \\
& (n=0) \\
& \text { Reports of included studies } \\
& (n=28)
\end{aligned}
$$

Figure 1. Flowchart illustrating the different phases of the search and selection of the studies Note: PRISMA (2020) flow diagram for new systematic reviews which included searches of databases and registers only.

Discussion

This systematic review has explored the association between PA and PF on AP and EF in elementary school children (6-12 years old). Studies from January 2010 to January 2021 were obtained from 4 databases. A total of 26 articles met the inclusion criteria: 9 studies used a cross-sectional design, 6 were repeated measures studies and 11 were intervention studies. PA and levels of PF were assessed by CRF, muscular strength, speed-agility, motor coordination, perceptual-motor skill and other physical variables.

A large number of studies have examined, through crosssectional designs, the association between the level of PF and various cognitive functions at school. The detailed analysis of the influence of each physical fitness component revealed that CRF has the greatest influence on AP and EF. To evaluate CRF, some studies used the 20-m shuttle run test PACER (Wittberg et al., 2012; Lambourne et al., 2013; Hansen, et al., 2014) and two studies used a formula to calculate the maximal oxygen consumption (VO.max) (Pontifex et al., 2012; Raine et al., 2013). Wittberg et al. (2012), Lambourne et al. (2013) and Hansen et al. (2014) found that children with more CRF had a higher AP. On the other hand, Pontifex et al. (2012) and Raine et al. (2013) used a computerised indirect calorimetry system with averages for oxygen uptake (VO.) and respiratory exchange ratio to assess CRF, showing how children with a high level of CRF had better memory ability. A suitable PF is an 
possible condition for better inhibition, working memory and cognitive flexibility in children (Syväoja et al., 2014; van der Niet et al., 2015). In addition, a good CRF, an adequate body composition, and a higher motor performance are associated better AP (Haapala et al., 2014). However, Jansen et al. (2019) did not find relationship between PF (body coordination and speed) and working memory in school-aged children.

Some research has focused on determining the acute and chronic effect of PA on children's cognitive abilities. The type of effect depended on the duration of the intervention carried out. Several research has shown a acute effect when children perform PA before academic subjects on AP and $E F$. Different PE classes in which children have to activate their brain function, lead to they are more prone to obtain better scores on AP, memory, attention or concentration (Yanagisawa et al., 2010). MVPA performed in a PE session has an acute effect on different EF like planning, attention, simultaneous processing and successive processing and school performance in children during elementary school (Pirrie and Lodewyk, 2012). Moreover, short periods of aerobic exercise (20 seconds of high-intensity activity separated by 10 seconds of rest and repeated 8 times) have an important acute effect on attention in the next academic classes ( $\mathrm{Ma}$ et al., 2015). Team game sessions, which demand control and complex eye-hand coordination and require goal-directed behaviour, and aerobic exercises, based on high-intensity cardiomyopathy, help students to better develop inhibition, shifting and memory update of themselves to face scholary activities in an appropriate way (Jäger et al., 2015). This was also supported by authors such as Mezcua et al. (2019) who showed that short-term training of C-HIIT has benefits in cognitive functions. However, a team game session had a better result in cognitive function than a class in aerobic exercise because it is producing a cognitive compromise when the frontal lobe is activated in the execution (Yanagisawa et al., 2010). This statement attempts to explain how PE sessions which include a cognitive compromise can have an acute effect on the cognitive capacities of children. Thus, Gallotta et al. (2015) demonstrated in an experiment that those sessions that require cognition exercises like playing mini-games with coordination, meant students were able to develop their cognitive skills more effectively. However, van den Berg et al. (2016) did not find any improvement on memory, attention or the PA in children who did aerobic, coordination or strength sessions in comparison with children who were in the control group.

On the other hand, current research has demonstrated the chronic effect of PA on AP and EF for elementary school children. Most of them have performed PA programmes in which children increased the time dedicated to PA at school (Lind et al., 2018). Käll et al. (2014) carried out a controlled interventional study in a Swedish government programme (Handslaget) based on group play and other activities which increased the proportion of students who achieved national learning compared with three reference schools. Higher proportions of students in the intervention school achieved the national goals in all three subjects compared with the reference schools after initiation of the intervention programme. Sardinha et al. (2016) also performed an intervention study to assess AP of children after a three-year intervention dedicated to avoiding childhood obesity. The result of this intervention was positive regarding the national goals. On the other hand, active lessons of MVPA in the classroom for several weeks improved the AP and EF of students due to the fact that they exercise not only the body but also the cognitive processes reflected in the AP
(Mullender-Wijnsma et al., 2015; Erwin et al., 2012; Layne et al., 2021). Hillman et al. (2009) showed that an intervention over 9 months where children do short periods of moderateintense aerobic exercise can improve cognitive control and attention. Increasing the number of hours of PE at school (two hours), over at least 10 weeks, is a suitable method to enhance the students' marks and cognitive aspects such as working memory and attention (Fisher et al., 2011). Children who have physical afterschool sessions for two hours per week (over 9 months) performing MVPA achieve better results on their behaviour (analysing accuracy and reaction time) and on executive control such as modulated attentional, inhibition and cognitive flexibility (Hillman et al., 2014). Moreover, afterschool sessions based on aerobic exercises (Kamijo et al., 2011; Chaddock-Heyman et al., 2020) and cardiovascular and motor exercises (Ou et al., 2016) showed improvements in some EF such as memory work or inhibitory control and AP. Continuing with afterschool sessions performing MVPA is a good way to enhance children's cognitive functions. In addition, it is relevant to determine not only whether team games and aerobic exercises have an acute effect on PA, but also whether it has a chronic effect if carried out for several weeks on EF such as inhibition, shifting and update (Schmidt et al., 2015). However, de Greeff et al. (2016) did not find improvements in mathematical and language activities for the experiment group after a two-year intervention dedicated to active MVPA classes.

Limitations of research and implications for research and practice

The limitations of the study are manifested in the selected databases. Although relevant databases were used, others such as Scopus were ignored. In addition, all types of studies that met the inclusion criteria were attended without paying attention to factors that could determine the quality of the study, such as the sample size.

Finally, based on the measurement instruments of the different variables, the suitability of the same can be confirmed in consideration of the context where the measurement was carried out and the age of the sample. All reflect an appropriate degree of reliability and are tailored to the sample. Certainly, more innovative and effective techniques such as image analysis could have been used, however, in the educational field, which has a fairly large sample, the use of such instruments is very complicated.

The literature suggests that cognitive and academic performance of children not improved by limiting the time allocated to PE and PA (Trudeau and Shephard, 2008). Therefore, increasing the amount of time devoted to PA and so improving their PF can promote acute and chronic cognitive benefits on EF such as working memory, attention, inhibition and shifting have important implications for AP (Fisher et al., 2011). In addition, activity breaks can produce positive, chronic cognitive response. This literature review serves as the basis for future research in the field of educational psychology that promotes PA programs in the school context in primary education.

\section{Conclusion}

The present review found a total of 26 articles that analysed the association between PA with AP and EF in children. Nine articles focused on AP and fifteen on EF. Thirteen of those focused on attention and working memory and two on other EF like inhibition, shifting, cognitive flexibility, update

Cultura, Ciencia y Deporte | AÑo 2022 | VoLUMEN 17 | NUM. 51 | España | PÁG. 85 A 103 | ISSN: 1696-5043 
or planning. Most studies showed a positive relationship between PA on AP and EF. In the nine studies which analysed the effect of PA and PF on AP, only one did not find an association. Regarding $\mathrm{EF}$, in two studies PA did not produce any effects. CRF was the physical variable that was correlated with better AP and EF. On the other hand, active classes of MVPA and PE classes when children had to perform coordination exercises revealed a better acute effect. In addition, a large chronic effect was found mainly in children who carried out PE sessions over several weeks which involved cognitive compromises by means of coordination exercises. Finally, confounders could have played a pivotal role in these associations. Sex, age, BMI, sociodemographic factors, and previous marks must be taken into account. More research is needed to explain the effect of different types of PA on AP and EF to clarify the role of confounders and better predict the relationship between physical and cognitive variables. Intervention studies in which children have to move more at school or outside school are necessary in order to enhance cognitive processes which are used during the school day. Integrating educational departments, the school and the families can guarantee the cognitive and physical health of children. Promoting PA in children as a tool for improving cognitive aspects is everyone's responsibility.

\section{References}

Ahn, S., \& Fedewa, A. L. (2011). A meta-analysis of the relationship between children's physical activity and mental health. Journal of Pediatric Psychology, 36(4), 385-397. https ://doi.org/10.1093/jpepsy/jsq107

Álvarez-Bueno, C., Pesce, C., Cavero-Redondo, I., SánchezLópez, M., Martínez-Hortelano, J. A., \& Martínez-Vizcaíno, V. (2017). The Effect of Physical Activity Interventions on Children's Cognition and Metacognition: A Systematic Review and Meta-Analysis. In Journal of the American Academy of Child and Adolescent Psychiatry. https://doi.org/ 10.1016/j.jaac.2017.06.012

Anderson, P. (2002). Assessment and Development of Executive Function (EF) During Childhood. Child Neuropsychology, 8(2), 71-82. https://doi.org/10.1076/chin. 8.2.71.8724

Berrios Aguayo, B., Pantoja Vallejo, A., \& Latorre Román, P. Á. (2019). Acute effect of two different physical education classes on memory in children school-age. Cognitive Development. https://doi.org/10.1016/j.cogdev.2019.03.00

Best, J. R. (2010). Effects of physical activity on children's executive function: Contributions of experimental research on aerobic exercise. Developmental Review, 30(4), 331-351. https://doi.org/10.1016/j.dr.2010.08.001

Carriedo, A. \& González, C. (2019).Rendimiento Académico en Educación Física: Aspectos Académicos versus Físicodeportivos. Cultura_Ciencia_Deporte, 14(42), 225-232.

Chaddock-Heyman, L., Weng, T. B., Kienzler, C., Weisshappel, R., Drollette, E. S., Raine, L. B., \& Kramer, A. F. (2020). Brain network modularity predicts improvements in cognitive and scholastic performance in children involved in a physical activity intervention. Frontiers in Human Neuroscience, 14, 346. https://doi.org/10.3389/fnhum.2020 .00346

Chaddock, L., Pontifex, M. B., Hillman, C. H., \& Kramer, A. F. (2011). A review of the relation of aerobic fitness and physical activity to brain structure and function in children. Journal of the International Neuropsychological Society\#: JINS, 17(6), 975-985. https://doi.org/10.1017/S13556177110005 67

Chang, Y. K., Labban, J. D., Gapin, J. I., \& Etnier, J. L. (2012). The effects of acute exercise on cognitive performance: A metaanalysis. In Brain Research (Vol. 1453, pp. 87-101). https://d oi.org/10.1016/j.brainres.2012.02.068

de Greeff, J. W., Hartman, E., Mullender-Wijnsma, M. J., Bosker, R. J., Doolaard, S., \& Visscher, C. (2016). Long-term effects of physically active academic lessons on physical fitness and executive functions in primary school children. Health Education Research, 31(2), 185-194. https://doi.org/10.1093 /her/cyv102

Donnelly, J. E., Greene, J. L., Gibson, C. A., Sullivan, D. K., Hansen, D. M., Hillman, C. H., Poggio, J., Mayo, M. S., Smith, B. K., Lambourne, K., Herrmann, S. D., Scudder, M., Betts, J. L., Honas, J. J., \& Washburn, R. A. (2013). Physical activity and academic achievement across the curriculum (A + PAAC): rationale and design of a 3-year, cluster-randomized trial. BMC Public Health, 13(1), 307. https://doi.org/10.1186/1471 -2458-13-307

Donnelly, J. E., Hillman, C. H., Castelli, D., Etnier, J. L., Lee, S., Tomporowski, P., Lambourne, K., \& Szabo-Reed, A. N. (2016). Physical activity, fitness, cognitive function, and academic achievement in children: A systematic review. In Medicine and Science in Sports and Exercise (Vol. 48, Issue 6, pp. 1197-1222). https://doi.org/10.1249/MSS.000000000 0000901

Downs, S. H., \& Black, N. (1998). The feasibility of creating a checklist for the assessment of the methodological quality both of randomised and non-randomised studies of health care interventions. J Epidemiol Community Health, 52, 377384.

Ellemberg, D., \& St-Louis-Deschênes, M. (2010). The effect of acute physical exercise on cognitive function during development. Psychology of Sport and Exercise, 11(2), 122126. https://doi.org/10.1016/j.psychsport.2009.09.006

Erwin, H., Fedewa, A., \& Ahn, S. (2012). Student academic performance outcomes of a classroom physical activity intervention: A pilot study. International Electronic Journal of Elementary Education, 4(3), 473-487.

Fisher, A., Boyle, J. M. E., Paton, J. Y., Tomporowski, P., Watson, C., McColl, J. H., \& Reilly, J. J. (2011). Effects of a physical education intervention on cognitive function in young children: randomized controlled pilot study. BMC Pediatrics, 11(1), 97. https://doi.org/10.1186/1471-2431-11-97

Friedman, N. P., Miyake, A., Young, S. E., DeFries, J. C., Corley, R. P., \& Hewitt, J. K. (2008). Individual differences in executive functions are almost entirely genetic in origin. Journal of Experimental Psychology: General, 137(2), 201-225. https://d oi.org/10.1037/0096-3445.137.2.201

Gallotta, M. C., Emerenziani, G. P., Franciosi, E., Meucci, M., Guidetti, L., \& Baldari, C. (2015a). Acute physical activity and delayed attention in primary school students. Scandinavian Journal of Medicine \& Science in Sports, 25(3), e331-8. https: //doi.org/10.1111/sms.12310

Gallotta, M. C., Emerenziani, G. P., Franciosi, E., Meucci, M., Guidetti, L., \& Baldari, C. (2015b). Acute physical activity and delayed attention in primary school students. Scandinavian Journal of Medicine \& Science in Sports, 25(3), e331-e338. ht tps://doi.org/10.1111/sms.12310

García-Pinillos, F., Soto-Hermoso, V. M., \& Latorre-Román, P. A. (2016). How does high-intensity intermittent training 
affect recreational endurance runners? Acute and chronic adaptations: A systematic review. Journal of Sport and Health Science. https://doi.org/10.1016/j.jshs.2016.08.010

Gunnell, K. E., Poitras, V. J., LeBlanc, A., Schibli, K., Barbeau, K., Hedayati, N., Ponitfex, M. B., Goldfield, G. S., Dunlap, C., Lehan, E., \& Tremblay, M. S. (2019). Physical activity and brain structure, brain function, and cognition in children and youth: A systematic review of randomized controlled trials. Mental Health and Physical Activity. https://doi.org/10 .1016/j.mhpa.2018.11.002

Haapala, E. A., Poikkeus, A.-M., Tompuri, T., Kukkonen-Harjula, K., Leppänen, P. H. T., Lindi, V., \& Lakka, T. A. (2014). Associations of motor and cardiovascular performance with academic skills in children. Medicine and Science in Sports and Exercise, 46(5), 1016-1024. https://doi.org/10.12 49/MSS.0000000000000186

Hansen, D. M., Herrmann, S. D., Lambourne, K., Lee, J., \& Donnelly, J. E. (2014). Linear/nonlinear relations of activity and fitness with children's academic achievement. Medicine and Science in Sports and Exercise, 46(12), 2279-2285. https ://doi.org/10.1249/MSS.0000000000000362

Higgins, J. P. T., \& Green, S. (2011). Manual Cochrane de revisiones sistemáticas de intervenciones.

Hillman, C. H., Buck, S. M., Themanson, J. R., Pontifex, M. B., \& Castelli, D. M. (2009). Aerobic fitness and cognitive development: Event-related brain potential and task performance indices of executive control in preadolescent children. Developmental Psychology, 45(1), 114-129. https:// doi.org/10.1037/a0014437

Hillman, C. H., Pontifex, M. B., Castelli, D. M., Khan, N. A., Raine, L. B., Scudder, M. R., Drollette, E. S., Moore, R. D., Wu, C. T., \& Kamijo, K. (2014). Effects of the FITKids randomized controlled trial on executive control and brain function. Pediatrics, 134(4), e1063-71. https://doi.org/10.1542/peds.2 013-3219

Jäger, K., Schmidt, M., Conzelmann, A., \& Roebers, C. M. (2015). The effects of qualitatively different acute physical activity interventions in real-world settings on executive functions in preadolescent children. Mental Health and Physical Activity, 9, 1-9. https://doi.org/10.1016/j.mhpa.201 5.05.002

Jansen, P., Scheer, C., \& Zayed, K. (2019). Motor ability and working memory in Omani and German primary schoolaged children. PLOS ONE, 14(1), e0209848. https://doi.org/ 10.1371/journal.pone.0209848

Janssen, I., \& Leblanc, A. G. (2010). Systematic review of the health benefits of physical activity and fitness in schoolaged children and youth. Int J Behav Nutr Phys Act., 7(14795868), 40. https://doi.org/1479-5868-7-40[pii]>r10.1186/14 79-5868-7-40

Käll, L. B., Nilsson, M., \& Lindén, T. (2014). The Impact of a Physical Activity Intervention Program on Academic Achievement in a Swedish Elementary School Setting. Journal of School Health, 84(8), 473-480. https://doi.org/10. 1111/josh.12179

Kamijo, K., Pontifex, M. B., O'Leary, K. C., Scudder, M. R., Wu, C.-T., Castelli, D. M., \& Hillman, C. H. (2011a). The effects of an afterschool physical activity program on working memory in preadolescent children. Developmental Science, 14(5), 1046-1058. https://doi.org/10.1111/j.1467-7687.201 1.01054.x

Kamijo, K., Pontifex, M. B., O'Leary, K. C., Scudder, M. R., Wu, C.-T., Castelli, D. M., \& Hillman, C. H. (2011b). The effects of an afterschool physical activity program on working memory in preadolescent children. Developmental Science, 14(5), 1046-1058. https://doi.org/10.1111/j.1467-7687.201 1.01054.x

Kibbe, D. L., Hackett, J., Hurley, M., McFarland, A., Schubert, K. G., Schultz, A., \& Harris, S. (2011). Ten Years of TAKE 10! $(\circledR)$ : Integrating physical activity with academic concepts in elementary school classrooms. Preventive Medicine, 52 Supp/ 1, S43-50. https://doi.org/10.1016/j.ypmed.2011.01.0 25

Kvalø, S. E., Bru, E., Brønnick, K., \& Dyrstad, S. M. (2017). Does increased physical activity in school affect children's executive function and aerobic fitness? Scandinavian Journal of Medicine \& Science in Sports, 27(12), 1833-1841. h ttps://doi.org/10.1111/sms.12856

Layne, T., Yli-Piipari, S., \& Knox, T. (2021). Physical activity break program to improve elementary students' executive function and mathematics performance. Education 3-13, 49(5), 583-591. https://doi.org/10.1080/03004279.2020.17 46820

Lambourne, K., Hansen, D. M., Szabo, A. N., Lee, J., Herrmann, S. D., \& Donnelly, J. E. (2013). Indirect and direct relations between aerobic fitness, physical activity, and academic achievement in elementary school students. Mental Health and Physical Activity, 6(3), 165-171. https://doi.org/10.1016 /j.mhpa.2013.06.002

Latorre-Román, P. Á., Mora-López, D., \& García-Pinillos, F. (2016). Intellectual maturity and physical fitness in preschool children. Pediatrics International, 58(6), 450-455. https://doi.org/10.1111/ped.12898

Latorre Román, P. Á., Pinillos, F. G., Pantoja Vallejo, A., \& Berrios Aguayo, B. (2017). Creativity and physical fitness in primary school-aged children. Pediatrics International, 59(11), 1194-1199. https://doi.org/10.1111/ped.13391

Lees, C., \& Hopkins, J. (2013). Effect of aerobic exercise on cognition, academic achievement, and psychosocial function in children: a systematic review of randomized control trials. Preventing Chronic Disease, 10, E174. https://d oi.org/10.5888/pcd10.130010

Lemes, V., Gaya, A. R., Sadarangani, K. P., Aguilar-Farias, N. Rodriguez-Rodriguez, F., de Lucena Martins, C. M., ... \& Cristi-Montero, C. (2021). Physical fitness plays a crucial mediator role in relationships among personal, social, and lifestyle factors with adolescents' cognitive performance in a structural equation model. The cogni-action project. Frontiers in pediatrics, 9, 656916. https://doi.org/10.3389/fp ed.2021.656916

Lezak, M. D., Howieson, D. B., \& Loring, D. W. (2004). Neuropsychological assessment. Oxford University Press.

Lind, R. R., Geertsen, S. S., Ørntoft, C., Madsen, M., Larsen, M. N., Dvorak, J., Ritz, C., \& Krustrup, P. (2018). Improved cognitive performance in preadolescent Danish children after the school-based physical activity programme "FIFA 11 for Health" for Europe. A cluster-randomised controlled trial. European Journal of Sport Science, 18(1), 130-139. http s://doi.org/10.1080/17461391.2017.1394369

Lobelo, F., Muth, N. D., Hanson, S., \& Nemeth, B. A. (2020). Physical activity assessment and counseling in pediatric clinical settings. Pediatrics, 145(3), e20193992. https://doi.o rg/10.1542/peds.2019-3992

Ma, J. K., Le Mare, L., \& Gurd, B. J. (2015). Four minutes of in-class high-intensity interval activity improves selective attention in 9- to 11-year olds. Applied Physiology, Nutrition, and Metabolism, 40(3), 238-244. https://doi.org/10.1139/ap $\mathrm{nm}-2014-0309$ 
Mahar, M. T. (2011). Impact of short bouts of physical activity on attention-to-task in elementary school children. Preventive Medicine, 52, S60-S64. https://doi.org/10.1016/j. ypmed.2011.01.026

Mahar, M. T., Murphy, S. K., Rowe, D. A., Golden, J., Shields, A. T., \& Raedeke, T. D. (2006). Effects of a classroom-based program on physical activity and on-task behavior. Medicine and Science in Sports and Exercise, 38(12), 2086-2094. https: //doi.org/10.1249/01.mss.0000235359.16685.a3

Maher, C. G., Sherrington, C., Herbert, R. D., Moseley, A. M., \& Elkins, M. (2003). Reliability of the PEDro scale for rating quality of randomized controlled trials. Physical Therapy, 83(8), 713-721.

Marques, A., Santos, D. A., Hillman, C. H., \& Sardinha, L. B. (2018). How does academic achievement relate to cardiorespiratory fitness, self-reported physical activity and objectively reported physical activity: A systematic review in children and adolescents aged 6-18 years. British Journal of Sports Medicine, 52(16), 1039. https://doi.org/10.1136/bj sports-2016-097361

Moher, D., Liberati, A., Tetzlaff, J., Altman, D. G., \& PRISMA Group. (2009). Preferred Reporting Items for Systematic Reviews and Meta-Analyses: The PRISMA Statement. PLoS Medicine, 6(7), e1000097. https://doi.org/10.1371/journal.p med.1000097

Mullender-Wijnsma, M. J., Hartman, E., de Greeff, J. W., Bosker, R. J., Doolaard, S., \& Visscher, C. (2015). Improving Academic Performance of School-Age Children by Physical Activity in the Classroom: 1-Year Program Evaluation. Journal of School Health, 85(6), 365-371. https://doi.org/10.1111/josh.12259

Ou, F. K., Wegner, M., Niemann, C., \& Budde, H. (2016). Effects of Motor versus Cardiovascular Exercise Training on Children_s Working Memory. https://doi.org/10.1249/MSS.0000000000 000869

Page, M.J., McKenzie, J.E., Bossuyt, PM, Boutron, I., Hoffmann, T.C., Mulrow, C.D., et al. (2021). The PRISMA 2020 statement: an updated guideline for reporting systematic reviews. $B M J$, 71. https://doi.org/10.1136/bmj.n71

Pesce, C., Crova, C., Cereatti, L., Casella, R., \& Bellucci, M. (2009). Physical activity and mental performance in preadolescents: Effects of acute exercise on free-recall memory. Mental Health and Physical Activity, 2, 16-22. https ://doi.org/10.1016/j.mhpa.2009.02.001

Pirrie, A. M., \& Lodewyk, K. R. (2012). Investigating links between moderate-to-vigorous physical activity and cognitive performance in elementary school students. Mental Health and Physical Activity, 5(1), 93-98. https://doi.o rg/10.1016/j.mhpa.2012.04.001

Pontifex, M. B., Scudder, M. R., Drollette, E. S., \& Hillman, C. H. (2012). Fit and vigilant: the relationship between poorer aerobic fitness and failures in sustained attention during preadolescence. Neuropsychology, 26(4), 407-413. https://d oi.org/10.1037/a0028795

Raine, L. B., Lee, H. K., Saliba, B. J., Chaddock-Heyman, L., Hillman, C. H., \& Kramer, A. F. (2013). The Influence of Childhood Aerobic Fitness on Learning and Memory. PLOS ONE, 8(9), e72666. https://doi.org/10.1371/journal.pone.00 72666

Resaland, G. K., Moe, V. F., Aadland, E., Steene-Johannessen, J., Glosvik, Ø., Andersen, J. R., Kvalheim, O. M., McKay, H. A., Anderssen, S. A., \& ASK study group. (2015). Active Smarter Kids (ASK): Rationale and design of a clusterrandomized controlled trial investigating the effects of daily physical activity on children's academic performance and risk factors for non-communicable diseases. BMC Public Health, 15(1), 709. https://doi.org/10.1186/s12889-015-204 9-y

Ruiz-Ariza, A., Grao-Cruces, A., de Loureiro, N. E. M., \& Martínez-López, E. J. (2017). Influence of physical fitness on cognitive and academic performance in adolescents: A systematic review from 2005-2015. International Review of Sport and Exercise Psychology, 10(1), 108-133. https://doi.or g/10.1080/1750984X.2016.1184699

Sardinha, L. S., Marques, A., Minderico, C., Nio Palmeira, A., Martins, S., Santos, D. A., \& Ekelund, U. (2016). Longitudinal Relationship between Cardiorespiratory Fitness and Academic Achievement. Med. Sci . Sports Exerc, 48(5), 839844. https://doi.org/10.1249/MSS.0000000000000830

Schmidt, M., Egger, F., Benzing, V., Jäger, K., Conzelmann, A., Roebers, C. M., \& Pesce, C. (2017). Disentangling the relationship between children's motor ability, executive function and academic achievement. PLOS ONE, 12(8), e0182845. https://doi.org/10.1371/journal.pone.0182845

Schmidt, M., Jäger, K., Egger, F., Roebers, C. M., \& Conzelmann, A. (2015). Cognitively Engaging Chronic Physical Activity, but Not Aerobic Exercise, Affects Executive Functions in Primary School Children: A Group-Randomized Controlled Trial. Journal of Sport and Exercise Psychology, 37(6), 575-591. https://doi.org/10.1123/jsep.2015-0069

Segura-Martínez, P., Molina-García, J., Queralt, A., del Mar Bernabé-Villodre, M., Martínez-Bello, D. A., \& MartínezBello, V. E. (2020). An Indoor Physical Activity Area for Increasing Physical Activity in the Early Childhood Education Classroom: An Experience for Enhancing Young Children's Movement. Early Childhood Education Journal, 1-15. https://doi.org/10.1007/s10643-020-01125-6

Soga, K., Shishido, T., \& Nagatomi, R. (2015). Executive function during and after acute moderate aerobic exercise in adolescents. Psychology of Sport and Exercise, 16, 7-17. http s://doi.org/10.1016/j.psychsport.2014.08.010

Syväoja, H. J., Tammelin, T. H., Ahonen, T., Kankaanpää, A., \& Kantomaa, M. T. (2014). The Associations of Objectively Measured Physical Activity and Sedentary Time with Cognitive Functions in School-Aged Children. PLOS ONE, 9(7), e103559. https://doi.org/10.1371/journal.pone.01035 59

Tomporowski, P. D., Davis, C. L., Miller, P. H., \& Naglieri, J. A. (2008). Exercise and children's intelligence, cognition, and academic achievement. Educational Psychology Review, 20(2), 111-131. https://doi.org/10.1007/s10648-007-90570

Trudeau, F., \& Shephard, R. J. (2008). Physical education, school physical activity, school sports and academic performance. In International Journal of Behavioral Nutrition and Physical Activity (Vol. 5, Issue 1, p. 10). https://doi.org/1 0.1186/1479-5868-5-10

van den Berg, V., Saliasi, E., de Groot, R. H. M., Jolles, J., Chinapaw, M. J. M., \& Singh, A. S. (2016). Physical Activity in the School Setting: Cognitive Performance Is Not Affected by Three Different Types of Acute Exercise. Frontiers in Psychology, 7, 723. https://doi.org/10.3389/fpsyg.2016.007 23

van der Niet, A. G., Smith, J., Scherder, E. J. A., Oosterlaan, J., Hartman, E., \& Visscher, C. (2015). Associations between daily physical activity and executive functioning in primary school-aged children. Journal of Science and Medicine in Sport, 18(6), 673-677. https://doi.org/10.1016/j.jsams.2014 .09 .006 
Verburgh, L., Königs, M., Scherder, E. J. a, \& Oosterlaan, J. (2014). Physical exercise and executive functions in preadolescent children, adolescents and young adults: a meta-analysis. British Journal of Sports Medicine, 48(12), 973979. https://doi.org/10.1136/bjsports-2012-091441

Wittberg, R. A., Northrup, K. L., \& Cottrell, L. A. (2012a). Children's aerobic fitness and academic achievement: a longitudinal examination of students during their fifth and seventh grade years. American Journal of Public Health, 102(12), 2303-2307. https://doi.org/10.2105/AJPH.2011.30 0515

Wittberg, R. A., Northrup, K. L., \& Cottrell, L. A. (2012b). Children's Aerobic Fitness and Academic Achievement: A Longitudinal Examination of Students During Their Fifth and Seventh Grade Years. American Journal of Public Health, 102(12), 2303-2307. https://doi.org/10.2105/AJPH.2011.30 0515

Yanagisawa, H., Dan, I., Tsuzuki, D., Kato, M., Okamoto, M., Kyutoku, Y., \& Soya, H. (2010). Acute moderate exercise elicits increased dorsolateral prefrontal activation and improves cognitive performance with Stroop test. Neurolmage, 50(4), 1702-1710. https://doi.org/10.1016/j.ne uroimage.2009.12.023 